\title{
Pengaruh Pseudomonas PL01 dan Monosodium Glutamat Terhadap Bakteri Indigenous Pasir dalam Mendegradasi Plastik
}

\author{
Intan Prima Sari dan Maya Shovitri \\ Departemen Biologi, Fakultas Ilmu Alam, Institut Teknologi Sepuluh Nopember (ITS) \\ e-mail:maya@bio.its.ac.id
}

\begin{abstract}
Abstrak - Kantong plastik sering digunakan karena sifatnya yang kuat, ringan, tahan lama, dan inert. Peningkatan jumlah penggunaan plastik dapat menjadi polutan bagi lingkungan. Salah satu alternatif penangannya adalah melalui proses biodegradasi oleh bakteri. Tujuan dari penelitian ini adalah mengetahui pengaruh Pseudomonas PL01 dan monosodium glutamat (MSG) terhadap bakteri indigenous pasir dalam mendegradasi plastik pada skala lapangan dengan metode penimbunan. Plastik berukuran $6 \times 10 \mathrm{~cm}$ ditimbun pada tanah pasir dengan kedalaman $10 \mathrm{~cm}$ lalu ditambahkan Pseudomonas PL01 dan/atau $1 \mathrm{~g} / \mathrm{L}$ MSG dalam polybag yang diletakkan di ruang terbuka, lalu diinkubasi selama 12 minggu. Setiap 3 minggu dilakukan pengukuran kepadatan sel biofilm pada permukaan plastik, visualisasi biofilm menggunkan methylene blue dan velositas. Hasil penelitian menunjukkan bahwa penambahan Pseudomonas PL01 dan/atau 1 g/L MSG dapat berpengaruh pada bakteri indigenous pasir dalam mendegradasi plastik. Kepadatan sel pada bakteri indigenous pasir tanpa penambahan Pseudomonas PL01 dan/atau 1 g/L MSG pada plastik hitam mencapai 1,16 AU. Pengukuran velositas juga menunjukkan adanya perubahan waktu apung plastik dari minggu ke-3 yaitu 18,45 detik menjadi 40,34 detik pada minggu ke-12.
\end{abstract}

Kata Kunci-Biodegradasi, Bakteri Indigenous Pasir, MSG, Pseudomonas PL01, Hidrofilik.

\section{PENDAHULUAN}

$\mathrm{P}$ LASTIK merupakan polimer sintetik yang memiliki berat molekul tinggi dan dibentuk melalui proses polimerisasi [1]. Penggunaan plastik dalam kehidupan sehari-hari semakin meningkat, seiring dengan perkembangan jaman dan peningkatan jumlah penduduk [2]. Salah satu jenis plastik yang sering digunakan adalah kantong plastik, karena sifatnya yang kuat, ringan, tahan lama, tahan korosi, tahan panas, murah dan inert [3]. Kantong plastik merupakan plastik jenis polietilena dengan polimer LDPE (Low Density Polyethylene). Polietilena merupakan polimer sintetik yang terbentuk dari rantai panjang monomer etilena [4].

Penggunaan plastik di seluruh dunia terus berkembang., yaitu sekitar 140 juta ton polimer sintetik diproduksi setiap tahunnya dengan penggunaan plastik jenis polietilena rata-rata $12 \%$ per tahun [5]. Peningkatan jumlah penggunaan plastik tersebut dapat menyebabkan berbagai masalah lingkungan, karena plastik termasuk salah satu jenis polutan yang tidak dapat berubah bentuk dalam waktu singkat di lingkungan [3]. Oleh karena itu, perlu adanya penanganan terkait masalah sampah plastik tersebut, salah satunya melalui proses biodegradasi. Biodegradasi merupakan proses dimana mikroorganisme seperti jamur dan bakteri mampu mendegradasi polimer alami (lignin, selulosa) dan polimer sintetik (polietilena, polistirena) [1]. Proses biodegradasi plastik di dalam tanah dapat dibantu oleh populasi mikroba indigenous tanah. Monosodium Glutamat (MSG) merupakan garam natrium yang berikatan dengan asam amino berupa asam glutamat dan berbentuk kristal putih yang stabil dan diketahui mampu meningkatkan pertumbuhan mikroorganisme [6]. Tanah jenis pasir merupakan salah satu sumber daya alam yang paling mudah diakses dan merupakan bahan granular alami yang terdiri dari batuan halus dan partikel mineral. Dari segi kimia, tanah pasir cukup mengandung unsur fosfor $(\mathrm{P})$ dan kalium (K), tetapi lahan pasir kekurangan unsur nitrogen $(\mathrm{N})$, sehingga kandungan nutrisi bagi tanaman maupun mikroorganisme pada pasir kurang terpenuhi [7]. Rendahnya nutrisi pada pasir tersebut, dapat dimanfaatkan sebagai media untuk proses biodegradasi plastik, dimana mikroorganisme indigenous distimulus untuk menggunakan plastik sebagai sumber karbon.

Dengan metode penimbunan (soil burial) pada skala laboraturium, bakteri Pseudomonas PL01 dan bakteri indigenous pasir dengan penambahan 1g/L MSG mampu bersinergi dalam mendegradasi plastik hitam, putih dan transparan masing-masing sebesar $7 \%, 12 \%$ dan $14 \%$ selama 16 minggu masa inkubasi [8]. Penelitian ini merupakan penelitian lanjutan yang bertujuan untuk mengetahui pengaruh Pseudomonas PL01 dan monosodium glutamat terhadap bakteri indigenous pasir saat diaplikasikan pada skala lapangan dengan metode penimbunan di dalam kantong polybag.

\section{METODOLOGI}

\section{A. Waktu dan Tempat Penelitian}

Penelitian ini dilaksanakan pada bulan Februari-Mei 2017 di lahan terbuka dan Laboraturium Mikrobiologi dan Bioteknologi, Jurusan Biologi, Fakultas Matematika dan Ilmu Pengetahuan Alam, Institut Teknologi Sepuluh Nopember, Surabaya.

\section{B. Preparasi Kantong Plastik}

Plastik uji yang digunakan berupa kantong plastik yang dipotong dengan ukuran $10 \times 6 \mathrm{~cm}$ sebanyak 3 kali pengulangan. Plastik direndam dengan alkohol $70 \%$ selama 30 menit dan dikeringanginkan di bawah sinar UV pada Laminar Air Flow (Bio 60-M) selama 15 menit. Plastik kemudian dimasukkan ke dalam oven (Memmert) pada suhu $80^{\circ} \mathrm{C}$ selama 24 jam. Setelah itu, plastik dimasukkan ke dalam desikator selama 24 jam [9]. 


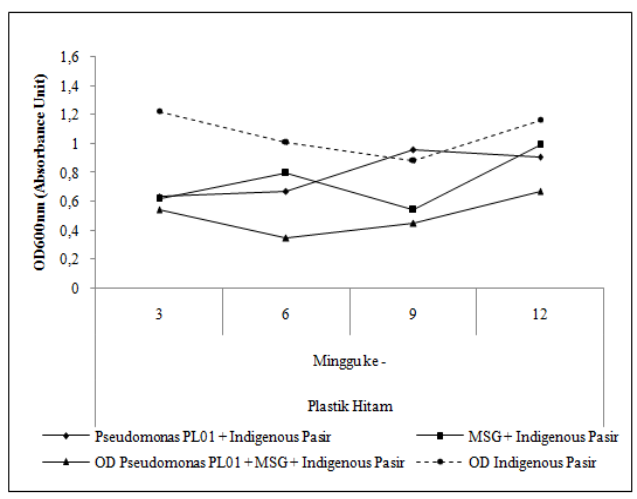

Gambar 1. Kepadatan Sel Bakteri Indigenous Pasir dengan Penambahan Pseudomonas PL01 dan/atau $1 \mathrm{~g} / \mathrm{L}$ MSG pada Permukaan Plastik.

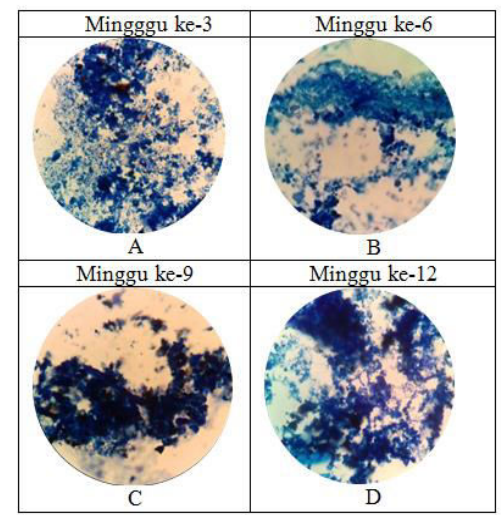

Gambar 2. Visualisasi Biofilm Bakteri Indigenous Tanah dan Bakteri Pseudomonas PL01 pada Plastik Transparan dengan Perbesaran 1000x : A) $\mathrm{OD}_{600 \mathrm{~mm}}=0,60 \mathrm{AU}$; B) $\mathrm{OD}_{600 \mathrm{~mm}}=0,42 \mathrm{AU}$; C) $\mathrm{OD}_{600 \mathrm{~mm}}=0,47 \mathrm{AU}$ dan $\left.\mathrm{D}\right)$ $\mathrm{OD}_{600 \mathrm{~mm}}=0,74 \mathrm{AU}$.

\section{Peremajaan Isolat dan Pembuatan Starter Bakteri}

Isolat diambil sebanyak 1 ose dan digoreskan secara garis continue ke permukaan medium NA dalam cawan Petri dan diinkubasi pada inkubator dengan suhu $37^{\circ} \mathrm{C}$ selama 24 jam. Pembuatan strater dilakukan secara bertingkat, dimulai dengan pengambilan inokulum dari isolat subkulktur sebanyak 1 ose dan dimasukkan ke dalam $10 \mathrm{ml}$ Nutrient Broth(NB), kemudian diinkubasi selama 24 jam. Biakan bakteri tersebut kemudian diambil sebanyak $1 \mathrm{ml}$, dimasukkan ke dalam $9 \mathrm{ml}$ NB baru dan diinkubasi selama 24 jam. Biakan bakteri $10 \mathrm{ml}$ tersebut selanjutnya dimasukkan ke dalam $90 \mathrm{ml} \mathrm{NB}$ baru dan diinkubasi selama 24 jam. Biakan bakteri $100 \mathrm{ml}$ tersebut selanjutnya dimasukkan ke dalam $900 \mathrm{ml}$ NB baru dan diinkubasi selama 24 jam. Pembiakan bakteri pada media NB ini adalah starter yang digunakan untuk proses selanjutnya. Starter yang digunakan berisi isolat bakteri dengan kepadatan sel $10^{8} \mathrm{sel} / \mathrm{ml}$ yang dihitung menggunakan Haemacytometer.

\section{Persipan Inokulum Aplikasi}

Starter bakteri yang digunakan sebanyak $10 \%$ dari volume total inokulum aplikasi. Air kolam diambil sebanyak $5400 \mathrm{ml}$, disaring dan disterilisasi dengan suhu $>100^{\circ} \mathrm{C}$. Inokulum aplikasi dibuat dengan cara mencampurkan $600 \mathrm{ml}$ starter bakteri dengan $5400 \mathrm{ml}$ air kolam steril, lalu dihomogenkan dan siap untuk diaplikasikan pada pasir. Terdapat 2 jenis inokulum aplikasi yang digunakan, yaitu dengan penambahan $1 \mathrm{~g} / \mathrm{L}$ MSG dan tanpa penambahan $1 \mathrm{~g} / \mathrm{L}$ MSG.

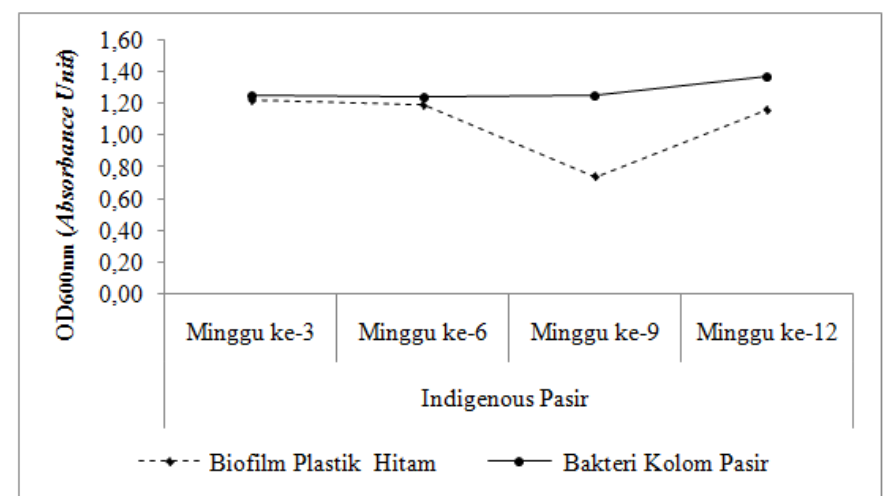

Gambar. 3. Perbandingan Pertumbuhan Bakteri Kolom Tanah Pasir dengan Biofilm Permukaan Plastik pada Bakteri Indigenous Pasir.

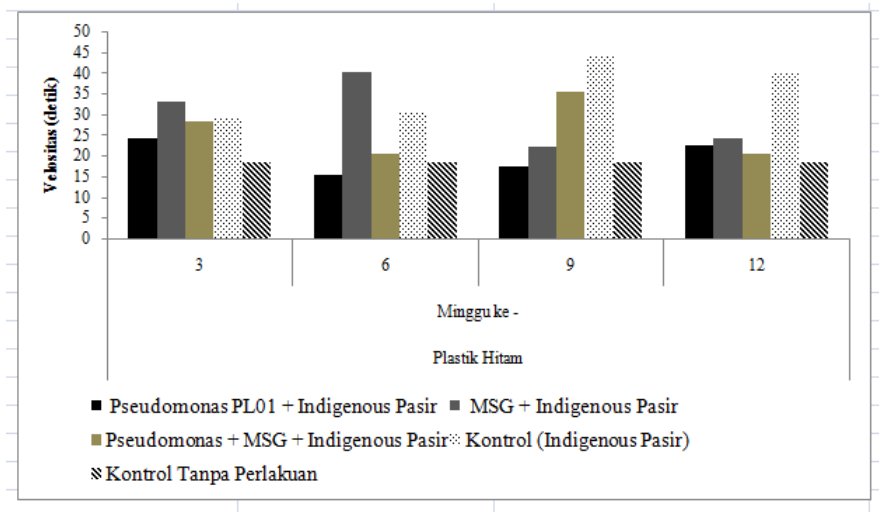

Gambar. 4. Velositas Plastik Bakteri Indigenous Pasir dengan Penambahan Pseudomonas PL01 dan/atau 1 g/L MSG.

\section{E. Biodegradasi Plastik}

Biodegradasi plastik dilakukan dengan menggunakan metode penimbunan tanah (soil burial method) [10]. Tanah yang digunakan merupakan tanah pasir pantai yang berasal dari Lumajang. Digunakan $6000 \mathrm{ml}$ inokulum aplikasi untuk dicampurkan dengan $30 \mathrm{~kg}$ pasir pada setiap kantong polybag berdiameter $60 \mathrm{~cm}$. Polybag diisi dengan pasir yang telah bercampur dengan inokulum aplikasi setinggi $10 \mathrm{~cm}$ [11]. Masing-masing plastik hitam, putih dan transparan ditata sebanyak 1 lembar dengan jarak setiap plastik selebar $3 \mathrm{~cm}$, kemudian ditimbun kembali dengan pasir setinggi $10 \mathrm{~cm}$. Setiap plastik dilakukan 3 kali pengulangan pada setiap polybag. Kontrol yang digunakan adalah pasir pantai tanpa penambahan isolat bakteri Pseudomonas PL01 dan MSG. Setiap 3 minggu sekali, plastik dipanen dengan cara digali tanah pada polybag secara perlahan hingga plastik terlihat, kemudian plastik diambil menggunakan pinset steril dan dimasukkan ke dalam botol falcon yang terlah berisi aquades steril. Selanjutnya dilakukan pengukuran Optical Density (OD), visualisasi biofilm dan velositas.

\section{F. Pengukuran Optical Dencity (OD)}

Biofilm pada plastik dilepaskan dengan cara lembar plastik yang telah dipanen, dimasukkan ke dalam botol falcon $50 \mathrm{ml}$ yang telah berisi $20 \mathrm{ml}$ aquades dan divortex dengan kecepatan 2500 rpm selama 30 detik sebanyak 3 kali. Larutan dari pelepasan biofilm tersebut kemudian diukur kepadatan 
selnya. Sebagai pembanding, dilakukan pengukuran densitas bakteri pada tanah disekitar area penimbunan plastik. Sebanyak $2 \mathrm{~g}$ tanah dicampur dengan $10 \mathrm{ml}$ air, kemudian diukur kepadatan selnya dengan cara yang sama.

\section{G. Deteksi Visual Biofilm}

Sisa larutan dari pelepasan biofilm diteteskan pada kaca objek dan dilakukan fiksasi di atas api bunsen. Kaca objek yang telah difiksasi kemudian diwarnai dengan methylene blue selama 1-2 menit. Kaca objek dibilas dengan aquades secara perlahan dan dikeringanginkan. Kaca objek diamati dengan mikroskop pada perbesaran 1000x dengan bantuan minyak imersi pada kaca penutup.

\section{H. Velositas}

Pengukuran velositas dilakukan berdasarkan penelitian [11], yaitu dengan cara plastik yang telah diukur berat keringnya kemudian dimasukkan kedalam inkubator kaca yang telah berisi aquades dengan ketinggian $10 \mathrm{~cm}$, menggunakan spatula steril sebagai penahannya. Spatula diangkat secara perlahan dan dilakukan pengamatan waktu yang dibutuhkan oleh plastik dari dasar inkubator hingga mencapai permukaan menggunakan stopwatch.

\section{HASIL DAN PEMBAHASAN}

\section{A. Kepadatan Sel}

Kepadatan sel yang diukur dengan serapan $\left(\mathrm{OD}_{600 \mathrm{~nm}}\right)$ merupakan biofilm yang terbentuk pada permukaan plastik. Biodegradasi pada material sintetik dimulai dengan pembentukan koloni dari mikroorganisme pada permukaan material padat, yang disebut biofilm [12]. Menurut [13] biofilm merupakan kumpulan dari sel mikroba yang saling berasosiasi dalam suatu permukaan dan tertutup dalam suatu matriks, terutama polisakarida. Biofilm akan terbentuk pada saat kondisi tercekam seperti kekurangan nutrisi pada lingkungan sekitarnya [14]. Pertumbuhan mikroorganisme pada tanah pasir terbatas karena nutrisi yang tidak mencukupi dan adanya kompetisi dengan flora mikroba [15]. Secara umum, pada Gambar 1 terlihat bahwa kepadatan sel pada kontrol yang merupakan bakteri indigenous pasir, lebih tinggi dibandingkan dengan kepadatan sel bakteri indigenous pasir dengan penambahan bakteri Pseudomonas PL01 dan/atau 1 g/L MSG. Selama 12 minggu masa inkubasi, kepadatan sel bakteri indigenous pasir dan Pseudomonas PL01 di permukaan plastik hitam mencapai 0,91 AU, sedangkan bila tanpa Pseudomonas PL01 kepadatan sel terlihat lebih tinggi, yaitu mencapai 1,16 AU. Hal ini mungkin berkaitan dengan stabilitas ekosistem mikroorganisme, dimana penambahan Pseudomonas PL01 diduga mengganggu kestabilan tersebut sehingga ada penurunan kepadatan sel. Hubungan antar organisme merupakan bentuk dari adaptasi pada lingkungan untuk mendukung metabolisme, proteksi atau suplai energi dan dapat distabilkan oleh organisme tersebut dengan cara mengontrol dan mengkoordinasikan interaksi yang dilakukan [16]. Stabilitas ekosistem dipengaruhi oleh konstruksi niche suatu mikroba [17]. Jika terlalu banyak tumpang tindih di ruang niche, dapat menyebabkan kepunahan spesies [18]. Penambahan Pseudomonas PL01 diduga mempengaruhi niche bakteri indigenous tanah dan membentuk hungungan yang saling merugikan dengan bakteri indigenous tanah. Hubungan ini dapat berupa kompetisi atau antagonisme karena ketidaksesuaian lingkungan bagi Pseudomonas PL01 untuk beradaptasi. Genus Pseudomonas diketahui mampu menghasilkan sejumlah besar metabolit sekunder dengan aktivitas antibakteri [19]. Senyawa metabolit sekunder merupakan senyawa yang dibentuk pada saat kondisi tercekam [20]. Penurunan kepadatan sel yang diduga akibat adanya Pseudomonas PL01 menyebabkan rendahnya pemanfaatan plastik oleh bakteri sebagai sumber karbon.

Kepadatan sel bakteri indigenous pasir dengan penambahan $1 \mathrm{~g} / \mathrm{L}$ MSG pada plastik hitam mencapai 0,99 AU. Namun, bila tanpa MSG kepadatan selnya juga terlihat lebih tinggi. Hal ini diduga karena bakteri indigenous pasir mampu memanfaatkan sumber nutrisi alternatif dari air kolam steril dan plastik sebagai sumber karbon untuk pertumbuhannya. Unsur penting di perairan yang mempengaruhi ketersediaan nutrien adalah nitrogen, fosfat dan karbon, dimana berperan penting dalam pembentukan biomassa mikroorganisme yang menentukan produktivitas primer perairan [21]. Sedangkan dengan adanya MSG, diduga bakteri indigenous tanah lebih memilih memanfaatkan kandungan glutamat untuk sintesis protein dalam menghasilkan enzim dibandingkan dengan pembentukan biomassa sel, sehingga kepadatan selnya rendah. Selanjutnya ketika bakteri indigenous pasir ditambah dengan bakteri Pseudomonas PL01 dan 1 g/L MSG, kepadatan sel terlihat paling rendah, yaitu mencapai 0,67 AU.

Rendahnya kepadatan sel pada penambahan bakteri Pseudomonas PL01 dan $1 \mathrm{~g} / \mathrm{L}$ MSG juga dapat dipengaruhi oleh faktor lingkungan, yaitu faktor biotik dan abiotik. Faktor biotik yang mempengaruhi rendahnya kepadatan sel diduga karena adanya kompetisi antara bakteri indigenous pasir dengan Pseudomonas PL01, yang dapat berupa persaingan dalam mendapatkan nutrisi. Sedangkan faktor abiotik yang dapat mempengaruhi pertumbuhan sel mikroorganisme diantaranya $\mathrm{pH}$, temperatur, tekanan, kelembaban [22]. Pada penelitian ini, faktor abiotik yang diukur adalah $\mathrm{pH}$ yang menunjukkan keadaan semakin asam selama 12 minggu masa inkubasi. Kondisi lingkungan $\mathrm{pH}$ dapat mempengaruhi sifat fisik enzim dan organisasi selular terhadap organisme [23]. Pseudomonas merupakan bakteri yang memiliki $\mathrm{pH}$ optimum 6,6-7 [24]. Hal ini menunjukkan bahwa pertumbuhan Pseudomonas PL01 diduga tidak optimum dalam kondisi $\mathrm{pH}$ 5-6. Menurut [25] komunitas bakteri tanah seringkali sangat berkorelasi dengan $\mathrm{pH}$ tanah, sehingga diduga bakteri indigenous pasir yang mampu hidup pada $\mathrm{pH}$ 5-6 hanya bakteri tertentu.

Kepadatan sel bakteri selain diukur dengan spektrofotometer (serapan $\mathrm{OD}_{600 \mathrm{~nm}}$ ), juga dapat dilihat dengan cara visualisasi biofilm menggunakan pewarna methylene blue. Gambar 2 menunjukkan hasil visualisasi biofilm bakteri indigenous pasir dan bakteri Pseudomonas PL01 pada permukaan plastik selama 12 minggu masa inkubasi.

Gambar 2 menunjukkan pada minggu ke-12, terlihat struktur biofilm yang berwarna biru dan paling tebal. Struktur biofilm yang terlihat secara umum sesuai dengan nilai kepadatan sel pada serapan $\mathrm{OD}_{600 \mathrm{~nm}}$. Semakin tinggi nilai kepadatan sel, maka semakin tebal struktur biofilm yang ditunjukkan dengan warna biru seperti gumpalan. Warna biru 
yang dihasilkan merupakan ikatan antara dinding sel dengan pewarna methylene blue.

Pengukuran kepadatan sel pada kolom tanah pasir juga dilakukan berdasarkan nilai $\mathrm{OD}_{600 \mathrm{~nm}}$ yang ditunjukkan pada Gambar 3. Hasil menunjukkan kepadatan sel biofilm pada permukaan plastik terlihat lebih rendah dibandingkan dengan kepadatan sel mikroorganisme kolom pasir. Hal ini dapat diasumsikan bahwa bakteri yang membentuk biofilm pada permukaan plastik merupakan mikroorganisme yang menggunakan plastik sebagai sumber karbon, sedangkan bakteri yang tidak menempel pada plastik merupakan mikroorganisme yang mampu tumbuh dengan memanfaatkan nutrisi selain plastik. Berdasarkan Gambar 3 tersebut, menunjukkan bahwa degradasi plastik menggunakan sumber alternatif air kolam steril di kantong polybag yang diletakkan pada ruang terbuka mengakibatkan bakteri cenderung menggunakan sumber nutrisi lain yang diduga berupa air kolam steril sehingga bakteri lebih menggunakan nutrisi tersebut daripada menempel pada plastik untuk menggunakan plastik sebagai sumber karbon.

\section{B. Velositas}

Pengukuran velositas merupakan adaptasi dari pengujian perubahan kecepatan terhadap perubahan waktu [26]. Velositas pada penelitian ini adalah untuk mengetahui hidrofilisitas plastik setelah terdegradasi [27]. Semakin lama waktu yang dibutuhkan plastik untuk mengapung sampai permukaan atas inkubator kaca, maka diasumsikan plastik akan semakin bersifat hidrofilik atau velositasnya semakin rendah. Berdasarkan hasil pengukuran kepadatan sel pada Gambar 1, terlihat bahwa bakteri indigenous pasir dan bakteri Pseudomonas PL01 dapat membentuk biofilm pada permukaan plastik. Adanya biofilm diasumsikan terjadi serangkaian reaksi enzimatik oleh bakteri terhadap polimer plastik yang menyebabkan plastik semakin bersifat hidrofilik. Sebagai pembanding, juga dilakukan pengukuran velositas plastik tanpa perlakuan degradasi sebagai kontrol tanpa perlakuan.

Secara umum, selama masa inkubasi dari minggu ke-3 sampai minggu ke-12 terlihat adanya pengurangan sifat hidrofobik pada plastik yang ditunjukkan dengan semakin lama waktu yang dibutuhkan plastik untuk naik ke permukaan. Pengurangan sifat hidrofobik dapat diakibatkan karena adanya biofilm yang terbentuk. Dari data velositas terlihat bahwa plastik yang sudah terdegradasi membutuhkan waktu yang lebih lama untuk mengapung ke permukaan dibandingkan dengan kontrol tanpa perlakuan yang memiliki velositas sebesar 18,45 detik. Pada grafik, terlihat bahwa pada kontrol bakteri indigenous pasir menunjukkan velositas yang lebih rendah dibandingkan dengan velositas bakteri indigenous pasir dengan Pseudomonas PL01. Velositas bakteri indigenous pasir mencapai 40,34 detik. Sedangkan velositas pada bakteri indigenous pasir dengan Pseudomonas PL01 mencapai 22,60 detik. Hal ini menunjukkan bahwa uji velositas berkorelasi positif dengan kepadatan sel. Selama masa inkubasi, terlihat adanya penurunan sifat hidrofobik. Gambar 4 menunjukkan plastik yang terdegradasi oleh bakteri indigenous pasir, velositas pada minggu ke-3 mencapai 29,38 detik, sedangkan velositas pada minggu ke-12 menurun menjadi 40,34 detik. Hal ini menunjukkan selama 12 minggu masa inkubasi, terjadi perubahan struktur polimer menjadi semakin hidrofilik akibat proses biodegradasi. Melekatnya bakteri ke polimer merupakan langkah awal pembentukan biofilm, dimana sifat hidrofobik permukaan sel mikroba sangat berperan dalam perlekatan terhadap polimer [28]. Ketika mikroorganisme menempel di permukaan, mereka akan tumbuh dan memanfaatkan polimer sebagai sumber karbon secara enzimatik dan menyebabkan polimer menjadi hidrofilik. Polietilena merupakan polimer sintesis yang memiliki hidrofobisitas dan berat molekul tinggi dikarenakan struktur polietilena yang memiliki ikatan kovalen antara $\mathrm{C}-\mathrm{C}$ dan $\mathrm{C}-\mathrm{H}$ [29]. Hidrofilik permukaan polimer dapat terjadi karna adanya pengenalan gugus fungsi oleh mikroorganisme selama proses degradasi.

\section{KESIMPULAN DAN SARAN}

Penambahan Pseudomonas PL01 dan $1 \mathrm{~g} / \mathrm{L}$ MSG dapat mempengaruhi bakteri indigenous pasir dalam mendegradasi plastik. Selama 12 minggu masa inkubasi, kepadatan sel bakteri indigenous pasir tanpa penambahan Pseudomonas PL01 dan $1 \mathrm{~g} / \mathrm{L}$ MSG pada permukaan plastik hitam yaitu 1,16 AU. Pengukuran velositas juga menunjukkan adanya perubahan waktu apung plastik dari minggu ke-3 yaitu 18,45 detik menjadi 40,34 detik pada minggu ke-12.

\section{DAFTAR PUSTAKA}

[1] H. Bhardwaj, R. Gupta, and A. Tiwari, "Microbial Population Associated With Plastic Degradation. Open Access Scientific Reports," Open Access Sci. Reports, vol. 1, no. 5, 2012.

[2] U.B. Surono, "Berbagai Metode Konversi Sampah Plastik menjadi Bahan Bakar Minyak," J. Tek., vol. 3, no. 1, pp. 32-40, 2013.

[3] A. Muthukumar and S. Veerappapillai, "Biodegradation of Plastics," Int. J. Pharm. Sci. Rev. Res., vol. 36, pp. 204-209, 2015.

[4] A. A. Hussein, I. K. Al-Mayaly, and S. H. Khudeir, "Isolation, Screening and Identification of Low Density Polyethylene (LDPE) Degrading Bacteria From Contaminated Soil with Plastic Wastes," Mesopotamia Environ. J., vol. 1, no. 4, pp. 1-14, 2015.

[5] S. Nanda, S. Sbigdha, and S. Sahu, "Biodegradability of Polyethylene by Brevibacillus, Pseudomonas and Rhodococcus spp," New York Sci. J., vol. 3, pp. 95-98, 2010.

[6] H. Nuryani and S. Jinap, "Soy Sauce and its Umami Taste: A Link from The Past To Current Situation," J. Food Sci., vol. 5, no. 3, pp. 71-76, 2010.

[7] Sunardi and Y. Sarjono, "Penentuan Kandungan Unsur Makro Pada Lahan Pasir Pantai Sasmas Bantul Dengan Metode Analisis Aktivasi Neutron (AAN)," in Prosiding PPI - PDIPTN. Pustek Akselerator dan Proses Bahan, 2007.

[8] R. Nafi'ah and M. Shovitri, "Degradasi Plastik Isolat Bakteri Bacillus PL01 dan Pseudomonas PL-01 Dengan Metode Penimbunan Dalam Tanah (Soil Burial) dan Penambahan Monosodium Glutamat," 2015.

[9] E. Zulaika, U. Sholikah, and A. Prasetya, "Potensi Bakteri Bacillus sebagai Agensia Bioremediasi Limbah Industri yang Mengandung Merkuri,” Institut Teknologi Sepuluh Nopember, 2012.

[10]K. Kathiseran, "Polythene and Plastics-Degrading Microbes From The Mangrove Soil," Rev. Biol. Trop, vol. 51, no. 3, pp. 629-634, 2003.

[11]E. B. Okoh and E. I. Atuya, "Impacts of Soil Composting and Poultry Manure on Biodegradation of Polyethylene," Int. J. Appl. Microbiol. Biotechnol. Res., vol. 2, pp. 18-29, 2014.

[12]B. M. Kyaw, R. Champakalakshmi, M. K. Sakharkar, C. S. Lim, and K R. Sakharkar, "Biodegradation of Low Density Polythene (LDPE) by Pseudomonas Species," Indian J. Microbiol., vol. 52, no. 3, pp. 411-419, 2012.

[13]M.D. Rodney, "Biofilms: Microbial Life on Surface," Infect. Dis. (Auckl)., vol. 8, no. 9, 2002.

[14]M. E. Olson, H. Ceri, D. W. Morck, A. . Buret, and R. R. Read, "Biofilm Bacteria: Formation and Comparative Susceptibility to Antibiotics," Can. 
J. Vet. Res., vol. 66, pp. 86-92, 2002.

[15]E. Velonakis, D. Dimitriadi, E. Papadogiannakis, and A. Votopoulos, "Present Status of Effect of Microorganisms From Sand Beach on Public Healt," J. Coast. Life Med., vol. 2, no. 9, pp. 746 - 756, 2014.

[16] G. D. A. Werner, W. K. C. Well, J. H. C. Cornelissen, and E. T. Kiers, "Evolutionary signals of symbiotic persistence in the legume-rhizobia mutualism," PNAS, vol. 112, no. 3, 2015.

[17] N. Lennon and J. T. Fierer, "The generation and maintenance of diversity in microbial communities," Am J Bot, vol. 98, pp. 439-448, 2011.

[18] J. T. Lennon and B. K. Lehmkuhl., "A Trait-Based Approach to Bacterial Biofilms in Soil," J. Environ. Microbiol., 2016.

[19] S. Tayeb, Z. Chama, A. Tifrit, F. Z. I. Reffas, and B. Abbouni., "Antagonistic activity of Pseudomonas aeruginosa ATCC 27853 Against Pathogenic Bacteria," J. Chem. Pharm. Res., vol. 7, no. 7, pp. $362-369$, 2015.

[20]R. Nofiani, "Urgensi dan Mekanisme Biosintesis Metabolit Sekunder Mikroba Laut," J. Natur Indones., vol. 10, no. 2, pp. 120 - 125, 2008.

[21]J. Horne and R. Goldman, Limnology. New York: The McGraw-Hill Companies, 1994.

[22] K. Zohreh, "The Effect of Biotic and Abiotic Factors on Degradation of Polycyclic Aromatic Hydrocarbons (PAHs) by Bacteria in Soil,"
University of Hertfordshire for the degree of Doctor of Philosophy, 2013.

[23] A.D. Brown, "Some General Properties of a Psychrophilic Pseudomonad: the Effects of Temperature on some of these Properties and the Utilization of Glucose by this Organism and Pseudomonas aeruginosa," $J$. gen. Microb., vol. 17, pp. $640-648,1957$.

[24] K. Todar, "Nutrition and Growth of Bacteria," 2013. [Online]. Available: http://textbookofbacteriology.net/nutgro_4.html.

[25] J. Rousk, E. Baath, P. C. Brookes, L. Lauber, C. Lozupone, and R. K. and N. F. J.G Caporaso, "Soil Bacterial and Fungal Communities Across a pH Gradient in an Arable Soil," ISME J., 2010.

[26]D. A. Wahyudi and I. H. Kartowisastro., "Menghitung Kecepatan Menggunakan Computer Vision,” Universitas Binus, 2011.

[27]J. W. Reisser, "Bouyant Plastics at Sea: Concentration and Impacts," 2015.

[28]P. Tribedi and A. K. Sil., "Cell Surface Hydrophobicity: a Key Component in The Degradation of Polyethylene Succinate by Pseudomonas sp. AKS2," J. Appl. Microbiol., vol. 116, pp. 295 - 303, 2013.

[29]L. H. Gabriel, O. N. Bennett, and B. Schneier, "Polyethylene Pipe Specifications," Washington D.C., 1995. 